\title{
Angiotensin II Receptor Blockade Limits Glomerular Injury in Rats with Reduced Renal Mass
}

\author{
Richard A. Lafayette, Gert Mayer, Sung K. Park, and Timothy W. Meyer \\ Departments of Medicine, Stanford University, Stanford, California 94305; and Palo Alto Veterans Administration Medical Center, \\ Palo Alto, California 94304
}

\section{Abstract}

The effects of angiotensin II (AII) blockade were compared with the effects of angiotensin converting enzyme inhibition in rats with reduced nephron number. Rats were subjected to fivesixths renal ablation and divided into four groups with similar values for blood pressure and serum creatinine after 2 wk. Group 1 then served as untreated controls, while group 2 received the AII receptor antagonist MK954 (which has previously been designated DuP753), group 3 received the converting enzyme inhibitor enalapril, and group 4 received a combination of reserpine, hydralazine, and hydrochlorothiazide. Micropuncture and morphologic studies were performed 10 wk later. Converting enzyme inhibition, AII receptor blockade, and the combination regimen were equally effective in reversing systemic hypertension (time-averaged systolic blood pressure: group 1, 185 $\pm 5 \mathrm{mmHg}$; group 2, 125 $\pm 2 \mathrm{mmHg}$; group 3, $127 \pm 2 \mathrm{mmHg}$; group 4, $117 \pm 4 \mathrm{mmHg}$ ). Micropuncture studies showed that glomerular transcapillary pressure was reduced significantly by converting enzyme inhibition and by AII blockade but not by the combination regimen ( $\delta \mathrm{P}$ : group $1,49 \pm 1$ mmHg; group 2, $42 \pm 1 \mathrm{mmHg}$; group $3,40 \pm 2 \mathrm{mmHg}$, group 4, $47 \pm 1 \mathrm{mmHg}$ ). Reduction of systemic blood pressure was associated with the development of markedly less proteinuria and segmental glomerular sclerosis in rats receiving enalapril and MK954 but not in rats receiving the combination regimen ( prevalence of glomerular sclerotic lesions: group 1, $41 \pm 4 \%$; group 2; $9 \pm 1 \%$; group $3,9 \pm 1 \%$; group $4,33 \pm 6 \%$ ). These results indicate that the effects of converting enzyme inhibition on remnant glomerular function and structure depend on reduction in AII activity and are not attributable simply to normalization of systemic blood pressure. (J. Clin. Invest. 1992. 766-771.) Key words: hypertension - glomerular sclerosis - proteinuria • nephrectomy • converting enzyme

\section{Introduction}

Inhibition of angiotensin converting enzyme has been shown to limit glomerular injury in several renal disease models (16 ). In rats with reduced nephron number, converting enzyme inhibition reduces both systemic and glomerular transcapillary pressure and slows the development of remnant glomerular sclerosis $(1,2)$. The current study sought to establish whether

Address correspondence to Richard A. Lafayette, M. D., Nephrology 111R, Palo Alto Veterans Administration Medical Center, 3801 Miranda Avenue, Palo Alto, CA 94304.

Received for publication 24 May 1991 and in revised form 10 March 1992.

The Journal of Clinical Investigation, Inc.

Volume 90, September 1992, 766-771 these beneficial effects of converting enzyme inhibition are mediated by a reduction in angiotensin II (AII) ${ }^{1}$ activity. Pharmacologic studies have shown that converting enzyme inhibitors not only limit production of AII but also increase levels of kinins and vasodilator prostaglandins (7-10). We therefore compared the effects of converting enzyme inhibition and AII receptor blockade in rats with reduced nephron number to determine whether converting enzyme inhibitor treatment protects remnant glomeruli by reducing AII activity.

\section{Methods}

Male Munich Wistar rats weighing 270-305 g were subjected to fivesixths renal ablation as previously described $(1,2) .2 \mathrm{wk}$ later they were divided into four groups matched for body weight, systolic blood pressure, and serum creatinine concentration. These groups were then followed for a further period of $10 \mathrm{wk}$ before micropuncture and morphologic studies. Group $1(n=13)$ received no treatment and served as controls. Group $2(n=10)$ received MK954 (Merck \& Co., Inc., West Point, PA), $180 \mathrm{mg} /$ liter, added to the drinking water. Group $3(n=9)$ received enalapril, $25 \mathrm{mg} /$ liter, added to the drinking water. Group 4 $(n=9)$ received a combination of reserpine $3 \mathrm{mg} /$ liter, hydralazine 40 $\mathrm{mg} /$ liter, and hydrochlorothiazide $13 \mathrm{mg} /$ liter, added to the drinking water. Each group had free access to standard laboratory chow. Systolic blood pressure was measured weekly by the tail cuff method. 24-h urine protein excretion was measured once after $4 \mathrm{wk}$ and twice after $9 \mathrm{wk}$ of treatment.

Micropuncture studies. Rats were anesthetized with Inactin, 100 $\mathrm{mg} / \mathrm{kg}$, intraperitoneally, and placed on a temperature-regulated micropuncture table. A PE-50 tubing catheter inserted in the left femoral artery was used for blood sampling and estimation of mean arterial pressure (AP). After tracheostomy PE-50 catheters were inserted in the internal jugular veins for infusion of saline, rat plasma obtained from retired breeder rats, and radiolabeled inulin. Saline was infused at a rate of $1.2 \mathrm{ml} / \mathrm{h}$ throughout the study. Plasma was infused in an amount equal to $1 \%$ body wt over $40 \mathrm{~min}$, followed by a reduction of the infusion rate to $0.5 \mathrm{ml} / \mathrm{h}$ for the remainder of the study. After $100 \mathrm{~min}$, tritiated-methoxy inulin was added to the saline to achieve an infusion rate of $40 \mu \mathrm{Ci} / \mathrm{h}$ following a loading dose of $\sim 30 \mu \mathrm{Ci}$.

Micropuncture measurements were then carried out over two or three 30-40-min clearance periods. In each period, a 200- $\mu$ l arterial blood sample was obtained for determination of hematocrit and plasma inulin and protein concentrations. A renal vein blood sample was obtained with each arterial blood sample for determination of filtration fraction by renal vein inulin extraction. Time averaged hydraulic pressures were measured in surface glomerular capillaries, proximal tubules, and efferent arterioles with a continuous recording servo-null

1. Abbreviations used in this paper: $\overline{\mathrm{AP}}$, mean arterial pressure; $\mathrm{AII}$, angiotensin II; $\bar{A}_{G}$, mean glomerular random cross-sectional area; $C_{A}$, protein concentration of arterial plasma; $C_{E}$, efferent arteriolar plasma protein concentration; $\Delta \mathbf{P}$, glomerular transcapillary hydraulic pressure; GFR, glomerular filtration rate; $K_{f}$, glomerular capillary ultrafiltration coefficient; $R_{A}$, afferent arteriolar resistance; $\overline{\mathbf{V}}_{\mathrm{G}}$, average glomerular tuft volume. 
micropipette transducer system (Model V; Instrumentation for Physiology and Medicine, San Diego, CA). Timed (4-min) samples of tubule fluid were collected from surface proximal nephrons for determination of single nephron glomerular filtration rate (SNGFR).

Morphometric studies. After micropuncture study kidneys were fixed by retrograde aortic perfusion with $1.25 \%$ glutaraldehyde in 0.1 $\mathrm{M}$ cacodylate buffer ( $\mathrm{pH} 7.4$ ). Kidney weight was measured in perfusion-fixed tissue. A transverse slice of kidney tissue was embedded in methacrylate and sections $5 \mu \mathrm{m}$ in thickness were then stained by the periodic acid-Schiff technique for light microscopy and measurement of mean glomerular volume. The frequency of focal and segmental glomerular sclerotic lesions was determined by examining all glomerular profiles (average $80 \pm 17$ [SD] profiles per animal) contained in a section from each kidney. Segmental lesions were specifically defined as areas of the tuft showing collapse of the glomerular capillaries accompanied by hyaline deposition and/or adhesion of the tuft to Bowman's capsule. For each animal, the number of glomeruli with segmental lesions was expressed as a percent of the total number of glomeruli counted. The average glomerular tuft volume $\left(\bar{V}_{\mathrm{G}}\right)$ of each animal was determined according to the procedure described by Weibel (11). For this purpose, the mean glomerular random cross-sectional area $\left(\bar{A}_{\mathrm{G}}\right)$ was determined on glomerular tuft profiles in the kidney section from each animal using a computer-assisted morphometric unit. $\left(\bar{V}_{\mathrm{G}}\right)$ was then calculated as

$$
\bar{V}_{\mathrm{G}}=\mathrm{B} / \mathrm{k} \cdot\left(\bar{A}_{\mathrm{G}}\right)^{3 / 2}
$$

where $\mathrm{B}=1.38$ is the shape coefficient for spheres (the idealized shape of glomeruli) and $\mathrm{k}=1.1$ is a size distribution coefficient $(11,12)$.

Analytical. Urine protein was measured by the Coomassie blue method. Serum creatinine was measured in tail blood samples using a Creatinine 2 Analyzer (Beckman Instruments, Palo Alto, CA). Protein concentration of arterial plasma $\left(C_{\mathrm{A}}\right)$ was determined by refractometry. Radioinulin content of plasma, urine, and tubule fluid was assessed by liquid-phase scintillation counting.

Calculations and statistics. Values for glomerular hemodynamic parameters for each animal were recorded as the mean of values obtained in that animal. Group mean values were then calculated as the mean of values for individual animals. Efferent arteriolar plasma protein concentration $\left(C_{\mathrm{E}}\right)$ was calculated from the relation:

$$
C_{\mathrm{E}}=\frac{C_{\mathrm{A}}}{1-\mathrm{FF}}
$$

Oncotic pressure $(\pi)$ of efferent and afferent arteriolar plasma was estimated from total protein concentration $(C)$ as

$$
\pi=1.629 \mathrm{C}+0.294 \mathrm{C}^{2}
$$

A standard mathematical model was used to derive the glomerular capillary ultrafiltration coefficient $\left(K_{\mathrm{f}}\right)$ from these values for oncotic pressure and from measured parameters (13). The statistical significance of differences among values for individual parameters in the four experimental groups was evaluated by the analysis of variance. Fisher's probability of least significant difference test was used to assess the significance of differences between individual group means (six comparisons) with significance defined as $P<0.05$. Results are expressed as means \pm SE throughout.

\section{Results}

Systolic blood pressure, serum creatinine, and body weight. Results of systolic blood pressure measurements in awake rats are depicted in Fig. 1. The four groups were matched for blood pressure at 2 wk after renal ablation. Untreated group 1 rats exhibited sustained hypertension with systolic blood pressure averaging $185 \pm 4 \mathrm{mmHg}$ over the remainder of the study period. In contrast, average systolic blood pressure over the 10wk treatment period was reduced to $125 \pm 2 \mathrm{mmHg}$ in group 2 rats, $127 \pm 2 \mathrm{mmHg}$ in group 3 rats, and $117 \pm 4 \mathrm{mmHg}$ in group

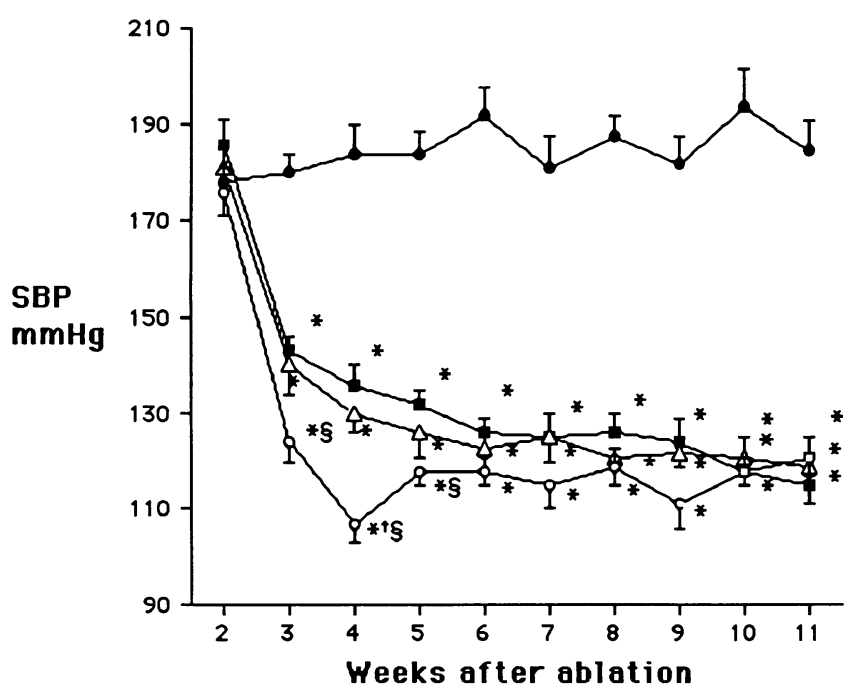

Figure 1. Systolic blood pressure ( $S B P$ ) after renal ablation. Groups were matched for blood pressure at 2 wk. Untreated group 1 rats $(\bullet)$ exhibited sustained hypertension over the remainder of the study. Blood pressure was reduced near to normal values by AII blockade in group 2 rats $(\Delta)$ by converting enzyme inhibition in group 3 rats $(\bullet)$, and by a combination of reserpine, hydralazine, and hydrochlorothiazide in group 4 rats $(0) .{ }^{*} P<0.05$ group 2,3 , or 4 vs group $1 ; \nmid P<0.05$ group 4 vs group $2 ; \S P<0.05$ group 4 vs group 3 .

4 rats. Average blood pressure values for the three treated groups were not statistically different from one another and were similar to blood pressure values observed in intact rats in our laboratory (14). The four experimental groups were also matched for serum creatinine (group $1,1.1 \pm 0.1 \mathrm{mg} / \mathrm{dl}$; group $2,1.2 \pm 0.1 \mathrm{mg} / \mathrm{dl}$; group $3,1.2 \pm 0.1 \mathrm{mg} / \mathrm{dl}$; group $4,1.1 \pm 0.1$ $\mathrm{mg} / \mathrm{dl}$ ) and for body wt (group 1, 276 $\pm 3 \mathrm{~g}$; group 2, 279 $\pm 4 \mathrm{~g}$; group 3, 269 $\pm 4 \mathrm{~g}$; group 4, 286 $\pm 8 \mathrm{~g}$ ) at $2 \mathrm{wk}$ after ablation. Weight gain was not different among the groups over the remainder of the study and averaged $58 \pm 4 \mathrm{~g}$ in group $1,65 \pm 4 \mathrm{~g}$ in group 2, 64 $\pm 2 \mathrm{~g}$ in group 3, and $50 \pm 7 \mathrm{~g}$ in group 4 .

Micropuncture studies. Mean values for hematocrit, arterial pressure under anesthesia $(\overline{\mathrm{AP}})$, whole kidney glomerular filtration rate (GFR), SNGFR, and the pressures, flows, and resistances governing glomerular ultrafiltration are summarized in Table I. Values for hematocrit were similar in the four groups. Values for $\overline{\mathrm{AP}}$ paralleled values for systolic blood pressure in awake animals. Untreated group 1 rats exhibited marked hypertension with $\overline{\mathrm{AP}}$ averaging $140 \pm 5 \mathrm{mmHg}$. AII receptor blockade reduced $\overline{\mathrm{AP}}$ to $98 \pm 4 \mathrm{mmHg}$ in group 2 rats, converting enzyme inhibition reduced $\overline{\mathrm{AP}}$ to $99 \pm 2 \mathrm{mmHg}$ in group 3 rats, and the combination regimen reduced $\overline{\mathrm{AP}}$ to $101 \pm 2 \mathrm{mmHg}$ in group 4 rats. Systemic hypertension was associated with elevation of glomerular transcapillary hydraulic pressure $(\Delta \mathrm{P})$ in untreated group 1 rats. The value of $49 \pm 1$ $\mathrm{mmHg}$ for $\Delta \mathrm{P}$ in these animals was similar to values observed in previous studies of rats subjected to renal ablation $(1,2)$. In contrast, $\Delta \mathbf{P}$ averaged $42 \mathrm{mmHg}$ in group 2 rats and $40 \pm 2$ $\mathrm{mmHg}$ in group 3 rats. Thus control of systemic hypertension by AII receptor blockade and by converting enzyme inhibition was associated with reduction of $\delta \mathrm{P}$ to values close to those observed in normal rats. Control of systemic hypertension by the combination regimen, however, was not associated with a similar reduction in $\Delta \mathrm{P}$. The average value for $\Delta \mathrm{P}$ in group 4 
Table I. Summary of Renal Cortical Microcirculation Studies

\begin{tabular}{|c|c|c|c|c|c|c|c|c|c|c|}
\hline & Het & $\overline{\mathrm{AP}}$ & $P_{G C}$ & $\mathbf{P}_{\mathbf{T}}$ & $\mathbf{P}_{\mathrm{E}}$ & $\Delta \mathbf{P}$ & GFR & SNGFR & FF & $\mathrm{Q}_{A}$ \\
\hline & $\%$ & $m m H g$ & \multicolumn{4}{|c|}{$\mathrm{mmHg}$} & $\mathrm{ml} / \mathrm{min}$ & $n l / m i n$ & $\%$ & $n l / m i n$ \\
\hline \multicolumn{11}{|l|}{ Group 1} \\
\hline$(n=11)$ & $43 \pm 1$ & $140 \pm 5$ & $65 \pm 1$ & $16 \pm 1$ & $17 \pm 1$ & $49 \pm 1$ & $0.85 \pm 0.06$ & $118 \pm 4$ & $0.29 \pm 0.02$ & $435 \pm 38$ \\
\hline \multicolumn{11}{|l|}{ Group 2} \\
\hline$(n=7)$ & $41 \pm 1$ & $98 \pm 4^{*}$ & $56 \pm 2^{*}$ & $14 \pm 1^{*}$ & $16 \pm 1$ & $42 \pm 2 *$ & $0.91 \pm 0.07$ & $107 \pm 6$ & $0.30 \pm 0.01$ & $358 \pm 22$ \\
\hline \multicolumn{11}{|l|}{ Group 3} \\
\hline$(n=7)$ & $41 \pm 1$ & $99 \pm 2 *$ & $54 \pm 2 *$ & $14 \pm 1^{*}$ & $14 \pm 1^{*}$ & $40 \pm 2^{*}$ & $0.96 \pm 0.06$ & $112 \pm 6$ & $0.28 \pm 0.01$ & $410 \pm 31$ \\
\hline \multicolumn{11}{|l|}{ Group 4} \\
\hline \multirow[t]{3}{*}{$(n=9)$} & $42 \pm 1$ & $101 \pm 2 *$ & $60 \pm 1^{* \pm}$ & $13 \pm 1^{*}$ & $17 \pm 1^{*}$ & $47 \pm 2^{\ddagger \S}$ & $0.72 \pm 0.05$ & $111 \pm 6$ & $0.27 \pm 0.01$ & $416 \pm 32$ \\
\hline & \multicolumn{2}{|l|}{$\mathrm{C}_{\mathrm{A}}$} & $\pi_{\mathrm{A}}$ & $\pi_{\mathrm{E}}$ & \multicolumn{2}{|l|}{$\mathbf{R}_{\mathbf{A}}$} & $\mathrm{R}_{\mathrm{E}}$ & \multirow[t]{2}{*}{$\mathbf{R}_{\mathbf{T}}$} & & $\mathrm{K}_{\mathrm{f}}$ \\
\hline & \multicolumn{2}{|l|}{$g / d l$} & \multicolumn{2}{|l|}{$m m H g$} & & & $d y n \cdot s \cdot \mathrm{cm}^{-s}$ & & \multicolumn{2}{|r|}{$n l /(s \cdot m m H g) \cdot 10^{3}$} \\
\hline \multicolumn{11}{|l|}{ Group 1} \\
\hline$(n=11)$ & \multicolumn{2}{|l|}{$5.7 \pm 0.1$} & \multirow[t]{2}{*}{$19 \pm 1$} & $32 \pm 1$ & \multicolumn{2}{|l|}{$0.81 \pm 0.06$} & $0.63 \pm 0.05$ & \multicolumn{2}{|l|}{$1.43 \pm 0.10$} & $83 \pm 4$ \\
\hline \multicolumn{10}{|l|}{ Group 2} & \\
\hline$(n=7)$ & \multicolumn{2}{|l|}{$5.5 \pm 0.1$} & \multirow[t]{2}{*}{$18 \pm 1$} & $31 \pm 2$ & \multicolumn{2}{|l|}{$0.56 \pm 0.05^{*}$} & $0.65 \pm 0.03$ & \multicolumn{2}{|l|}{$1.21 \pm 0.07$} & $109 \pm 11$ \\
\hline \multicolumn{10}{|l|}{ Group 3} & \\
\hline$(n=7)$ & \multicolumn{2}{|l|}{$5.6 \pm 0.1$} & \multirow[t]{2}{*}{$18 \pm 1$} & $30 \pm 1$ & \multicolumn{2}{|l|}{$0.51 \pm 0.02^{*}$} & $0.56 \pm 0.06$ & \multicolumn{2}{|l|}{$1.07 \pm 0.08^{*}$} & $137 \pm 25^{*}$ \\
\hline \multicolumn{10}{|l|}{ Group 4} & \\
\hline$(n=9)$ & $5.5 \pm 0.1$ & & $18 \pm 1$ & $30 \pm 1$ & $0.47 \pm 0.04^{*}$ & & $0.60 \pm 0.05$ & $1.07 \pm 0.07^{*}$ & & $80 \pm 4^{\ddagger}$ \\
\hline
\end{tabular}

Mean values \pm SEM.

Abbreviations: Hct, hematocrit; $\overline{\mathrm{AP}}$, mean arterial pressure; $\mathrm{P}_{\mathrm{GC}}$, mean glomerular capillary hydraulic pressure; $\mathrm{P}_{\mathrm{T}}$, proximal tubule hydraulic pressure; $P_{E}$, efferent arteriolar hydraulic pressure; $\Delta P$, mean glomerular transcapillary hydraulic pressure difference; GFR, glomerular filtration rate; SNGFR, single nephron glomerular filtration rate; $F F$, filtration fraction; $Q_{A}$, glomerular plasma flow rate; $C_{A}$, afferent arteriolar plasma protein concentration; $\pi_{A}$ and $\pi_{E}$, afferent and efferent arteriolar colloid osmotic pressure; $R_{A}$, afferent arteriolar resistance; $R_{E}$, efferent arteriolar resistance; $\mathrm{R}_{\mathrm{T}}$, total arteriolar resistance; $\mathrm{K}_{f}$, glomerular capillary ultrafiltration coefficient. ${ }^{*} P<0.05$ group 2,3 , or 4 vs group 1 ; group 4 vs group 2; ${ }^{\ddagger}$ group 4 vs group 3.

rats was $47 \pm 1 \mathrm{mmHg}$. This value was significantly greater than the values for $\Delta \mathrm{P}$ in groups 2 and 3 and only slightly and not significantly less than the value for $\delta \mathrm{P}$ in group 1 .

Despite the lower systemic blood pressures, values for remnant kidney GFR were not reduced in the treated groups, averaging $0.91 \pm 0.07 \mathrm{ml} / \mathrm{min}$ in group $2,0.96 \pm 0.06 \mathrm{ml} / \mathrm{min}$ in group 3 , and $0.72 \pm 0.5 \mathrm{ml} / \mathrm{min}$ in group 4 , as compared to a value of $0.85 \pm 0.06 \mathrm{ml} / \mathrm{min}$ in group 1 . As expected, rats subjected to renal ablation exhibited prominent remnant nephron hyperfiltration with values for SNGFR increased to more than twice those observed in normal rats (14). Persistant remnant nephron hyperperfusion, attributable largely to reductions in afferent arteriolar resistance, $\boldsymbol{R}_{\mathrm{A}}$, contributed to the maintenance of hyperfiltration when blood pressure was reduced by drug treatment. Increased values for the ultrafiltration coefficient, $K_{\mathrm{f}}$, also contributed to maintenance of hyperfiltration in groups 2 and 3 treated with AII blockade and converting enzyme inhibition, but the increase in $K_{\mathrm{f}}$ attained statistical significance only in group 3 . The mean value for $K_{\mathrm{f}}$ in group 4 rats receiving the combination regimen was practically identical to the mean value for $K_{\mathrm{f}}$ in group 1 rats receiving no treatment.

The effectiveness of AII receptor blockade and converting enzyme inhibition was confirmed by assessing the pressor responses to intravenous bolus infusions of angiotension I (AI) and AII at the end of the micropuncture studies. The pressor response to $50 \mathrm{ng}$ of $\mathrm{AI}$ was $56 \pm 4 \mathrm{mmHg}$ in group $1,7 \pm 2$ $\mathrm{mmHg}$ in group $2(P<0.05$ vs group 1$), 18 \pm 2 \mathrm{mmHg}$ in group
3 ( $P<0.05$ vs groups 1 and 2$)$, and $46 \pm 2 \mathrm{mmHg}$ in group 4 ( $P$ $<0.05$ vs groups 1,2 , and 3$)$. The pressor response to $50 \mathrm{ng}$ of AII was $55 \pm 6 \mathrm{mmHg}$ in group $1,8 \pm 2 \mathrm{mmHg}$ in group $2(P<$ 0.05 vs groups 1,3 , and 4 ), $54 \pm 3 \mathrm{mmHg}$ in group 3 , and $49 \pm 2$ $\mathrm{mmHg}$ in group 4. Thus both MK954 and enalapril reduced the pressor response to AI but only MK954 effectively reduced the pressor response to AII.

Proteinuria. Group 1 rats with systemic and glomerular hypertension developed progressive glomerular injury manifested by increasing proteinuria as depicted in Fig. 2. Protein excretion in this group averaged $145 \pm 22 \mathrm{mg} / \mathrm{d}$ at $6 \mathrm{wk}$ after ablation and $251 \pm 23 \mathrm{mg} / \mathrm{d}$ at $11 \mathrm{wk}$ after ablation. AII blockade and converting enzyme inhibition afforded equal protection against the development of proteinuria. Thus protein excretion in group 2 rats averaged $52 \pm 7 \mathrm{~mm} / \mathrm{d}$ at 6 wk after ablation and rose only to $85 \pm 16 \mathrm{mg} / \mathrm{d}$ at $11 \mathrm{wk}$ after ablation. Similarly, protein excretion in group 3 rats averaged $39 \pm 8 \mathrm{mg} /$ $\mathrm{d}$ at $6 \mathrm{wk}$ after ablation and rose only to $67 \pm 13 \mathrm{mg} / \mathrm{d}$ at $11 \mathrm{wk}$ after ablation. In contrast, reduction of blood pressure with the combination regimen did not afford effective protection against the development of proteinuria. At 6 wk after ablation, protein excretion in group 4 rats averaged $90 \pm 26 \mathrm{mg} / \mathrm{d}$, a value intermediate between the values observed in groups 2 and 3 and the value observed in group 1 . By 11 wk after ablation, however, protein excretion in group 4 rats averaged $247 \pm 34$ $\mathrm{mg} / \mathrm{d}$, a value close to that observed in group 1 rats receiving no treatment. 


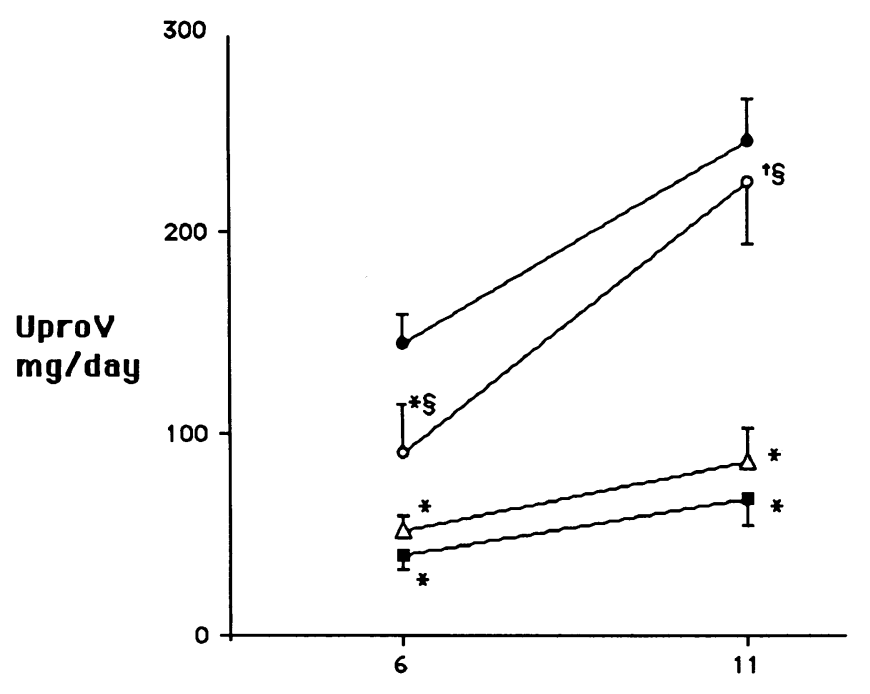

Weeks after ablation

Figure 2. 24-h urine protein excretion (UproV) at 6 and 11 wk after renal ablation. Untreated rats (group $1, \bullet$ ) developed heavy proteinuria. AII blockade (group 2, $\Delta$ ) and converting enzyme inhibition (group $3,-$ ) were equally effective in limiting development of proteinuria. The combination of reserpine, hydralazine, and hydrochlorothiazide (group 4,0 ) was less effective in limiting proteinuria at $6 \mathrm{wk}$ after ablation and ineffective in limiting proteinuria at $11 \mathrm{wk}$ after ablation. ${ }^{*} P<0.05$ group 2,3 , or 4 vs group $1 ; \uparrow \S P<0.05$ group 4 vs group 2 .

Structural alterations. Results of morphologic studies are summarized in Table II. These studies disclosed that the prevalence of segmental glomerular lesions was closely associated with the degree of proteinuria. Group 1 rats receiving no treatment exhibited segmental lesions in $41 \pm 3 \%$ of glomeruli. The prevalence of segmental glomerular lesions was $9 \pm 1 \%$ both in group 2 rats receiving MK954 and in group 3 rats receiving enalapril, indicating that AII blockade and converting enzyme inhibition provided equivalent protection against glomerular structural injury. In contrast, the prevalence of segmental glomerular lesions was $33 \pm 6 \%$ in group 4 rats, indicating that reduction of blood pressure with the combination regimen provided significantly less, if any, protection against glomerular injury. As expected, values for mean glomerular volume were greater than those obtained in intact rats in our laboratory (15). Protection against remnant glomerular injury was not, however, associated with a significant reduction in glomerular volume in rats receiving MK954 or enalapril. Average remnant kidney weight was slightly less in group 2 and 3 than in group 4 .

\section{Discussion}

Ablation of major portions of the renal mass in rats is followed by progressive sclerosis of remnant glomeruli $(1,2,16)$. Development of glomerular sclerosis in this model is preceded by systemic and glomerular hypertension and accompanied by steadily increasing proteinuria. Several therapies have been shown to retard the development of remnant glomerular injury in rats subjected to renal ablation (16). One of the most effective of these therapies is inhibition of angiotensin I converting enzyme. Doses of converting enzyme inhibitors which normal- ize systemic and glomerular transcapillary pressure have been shown to reduce proteinuria and largely prevent sclerosis of remnant glomeruli $(1,2)$.

The goal of this study was to better define the pharmacologic mechanism by which converting enzyme inhibitors protect remnant glomeruli. Specifically, we sought to determine whether the beneficial effects of converting enzyme inhibition are mediated by a reduction in AII activity. In intact rats, infusion of AII has been shown to increase glomerular transcapillary pressure and ultimately to cause progressive glomerular sclerosis $(17,18)$. Reduction in AII activity thus provides a logical mechanism for the protective effect of converting enzyme inhibition in rats subjected to renal ablation. Converting enzyme inhibitors, however, have other pharmacologic effects which could help lower blood pressure and preserve glomerular structure following reduction of nephron number. In particular, converting enzyme inhibitors increase the activity of kinins and may increase the activity of vasodilator prostaglandins ( 710 ). Recent studies suggest that increased activity of kinins contributes to the antiproteinuric effect of converting enzyme inhibition in rats with Heymann nephritis and to the antihypertensive effect of converting enzyme inhibition in rats with Goldblatt hypertension $(9,10)$.

To determine whether converting enzyme inhibition protects remnant glomeruli by reducing AII activity, we compared the effects of the AII receptor blocker MK954 and the converting enzyme inhibitor enalapril in rats subjected to renal ablation. MK954 is a nonpeptide AII receptor blocker which is highly specific for the AT-1 receptor and can be given orally $(19,20)$. Even in high concentrations, it has no agonist activity and blocks smooth muscle contraction in response to AII without affecting smooth muscle responses to agents including catecholamines, acetylcholine, and vasopressin $(21,22)$. It does not potentiate the vasodilator activity of kinins and its antihypertensive activity is unaffected by prostaglandin synthesis inhibition (21-23). Recent studies show further that MK954 does not inhibit thromboxane synthesis (A. T. Chiu, personal communication). The current micropuncture studies showed that MK954 and enalapril were equally effective in reducing systemic and glomerular transcapillary pressure in rats subjected to renal ablation. Morphologic studies showed that MK954 and enalapril were equally effective in preventing remnant glomerular sclerosis. Overall, the effects of AII receptor blockade

Table II. Summary of Morphologic Studies

\begin{tabular}{lccc}
\hline & Sclerosis & $\overline{\mathrm{V}}_{\mathbf{G}}$ & $\begin{array}{c}\text { Remnant } \\
\text { kidney } \\
\text { weight }\end{array}$ \\
\hline & $\%$ & $10^{6} \mu^{3}$ & $g$ \\
Group 1 $(n=12)$ & $41 \pm 3$ & $4.0 \pm 0.2$ & $1.96 \pm 0.09$ \\
Group 2 $(n=10)$ & $9 \pm 1^{*}$ & $3.8 \pm 0.2$ & $1.89 \pm 0.05$ \\
Group 3 $(n=9)$ & $9 \pm 1^{*}$ & $3.6 \pm 0.2$ & $1.78 \pm 0.06$ \\
Group 4 $(n=9)$ & $33 \pm 6^{\ddagger \S}$ & $3.6 \pm 0.2$ & $2.14 \pm 0.07^{\ddagger \S}$ \\
& & &
\end{tabular}

Mean values \pm SEM.

Sclerosis, prevalence of glomerular sclerotic lesions; $\overline{\mathrm{V}}_{\mathrm{G}}$, mean glomerular volume.

${ }^{*} P<0.05$ group 2,3 , or 4 vs group 1 ; ${ }^{\ddagger}$ group 4 vs group $2 ;{ }^{8}$ group 4 vs group 3 . 
were not distinguishable from those of converting enzyme inhibition. Results of the current study thus strongly suggest that converting enzyme inhibition prevents glomerular injury by reducing AII activity in rats subjected to renal ablation.

Results of our study do not prove that AII activity is increased after renal ablation. It is possible that renal ablation induces a primary disturbance in some other vasomotor control system, but that the effects of this disturbance on blood pressure and glomerular structure do not develop when AII activity is reduced. Alternatively, hypertension and glomerular injury in rats subjected to renal ablation could be caused by activation of the renin angiotension system. Early investigators showed that circulating renin levels are not elevated in rats with reduced nephron number (24). The hypothesis that increased renin release causes hypertension in these animals was therefore largely abandoned. It has since been recognized, however, that maintenance of "normal" values for circulating renin activity in the setting of increased blood pressure or sodium excretory load may reflect activation of the renin-angiotensin system $(25,26)$. Thus failure of plasma renin levels to decrease despite a prominent increase in blood pressure in rats subjected to renal ablation could reflect an increase in the activity of the circulating renin angiotensin system in these animals $(1,24)$. It is notable that Anderson et al. (27) found that plasma renin levels increased markedly when antihypertensive agents which have no direct effect on the renin angiotensin system were used to lower blood pressure in renal ablated rats. These findings suggest that enalapril and MK954 could maintain normal blood pressure following renal ablation by blocking the effect of an increase in circulating renin activity.

An additional possibility is that converting enzyme inhibition and AII receptor blockade prevent an increase in the intrarenal activity of the renin-angiotensin system following renal ablation. It has recently been recognized that local activity of the renin-angiotensin system may be increased without alteration of circulating renin levels $(28,29)$. Within the kidney, renin is released into the perivascular interstitium, and renin concentrations in renal lymph may exceed those in plasma (30). Angiotensinogen is also produced within the kidney, and intrarenal angiotensinogen synthesis may modulate intrarenal AII production independent of circulating renin activity (29). These observations have prompted interest in the possibility that intrarenal AII activity promotes hypertension and progressive glomerular injury in renal disease $(31,32)$. Proof that the activity of the intrarenal renin angiotensin system is increased in rats subjected to renal ablation has not yet been obtained. Recent studies suggest, however, that systemic and glomerular hypertension in rats subjected to renal ablation is caused by hypoperfusion of nephrons adjacent to areas of renal scarring (14). Hypoperfusion of this nephron population could presumably stimulate release of renin into the renal interstitium and thereby cause an increase in intrarenal AII activity.

Glomerular capillary pressure was reduced along with systemic blood pressure in renal ablated rats receiving enalapril and MK954 in the current study. Glomerular transcapillary pressure remained elevated, however, when blood pressure was reduced with a combination of reserpine, hydralazine, and hydrochlorothiazide. Findings in rats treated with enalapril and with the combination regimen were similar to those originally reported by Anderson et al. (27). The reason that these antihypertensive regimens have different effects on glomerular func- tion remains to be elucidated. Pelayo and Westcott (33) have recently shown that acute reduction of renal perfusion pressure by aortic constriction reduces glomerular capillary pressure in rats subjected to renal ablation. Anderson et al. (27) showed that sustained reduction of systemic pressure by administration of reserpine, hydralazine, and hydrochlorothiazide is associated with elevation of plasma renin levels as well as with maintenance of glomerular hypertension in this disease model. Together, these results suggest that glomerular transcapillary pressure might initially be reduced by any therapy which reduces systemic blood pressure, but that blockade of AII activity may be necessary for sustained reduction of glomerular transcapillary pressure along with systemic blood pressure in rats subjected to renal ablation.

Finally, it should be emphasized that the current study does not identify the mechanism by which reducing AII activity preserves remnant glomerular structure. Protection against glomerular sclerosis was associated with reduction of glomerular transcapillary pressure both in rats receiving MK954 and in rats receiving enalapril. These findings are consistent with the hypothesis that glomerular injury in rats subjected to renal ablation is caused by capillary hypertension $(1,2)$. The effects of AII on the glomerulus, however, are not limited to increasing transcapillary pressure. In vitro studies have shown that AII causes growth of smooth muscle and mesangial cells and may cause proliferation of these cells (34-36). A sustained increase in intrarenal AII activity could thus cause progressive mesangial expansion. The finding that glomerular epithelial cells have AII receptors suggests that AII could also have a direct effect on glomerular barrier function (37). At present, it is not possible to selectively block any one of these actions of AII without also blocking the others. It is thus not possible to determine whether AII receptor blockade protects remnant glomeruli by lowering glomerular transcapillary pressure or by preventing some other action of AII in the remnant kidney.

\section{Acknowledgments}

We are grateful to Brittmarie Anderssen and to Helen Kwan for expert technical assistance.

Supported by grants from the Research Service of the Veterans Administration, the National Institutes of Health (DK 42093), and Merck Inc. Dr. Lafayette was the recipient of a Fellowship award from the California Affiliate of the American Heart Association, Dr. Mayer was the recipient of a Fellowship award from the Max Kade Foundation, and Dr. Park was the recipient of a Fellowship award from the Juvenile Diabetes Foundation.

\section{References}

1. Anderson, S., T. W. Meyer, H. G. Rennke, and B. M. Brenner. 1985. Control of glomerular hypertension limits glomerular injury in rats with reduced renal mass. J. Clin. Invest. 76:612-619.

2. Meyer, T. W., S. Anderson, H. G. Rennke, and B. M. Brenner. 1987. Reversing glomerular hypertension stabilizes established glomerular injury. Kidney Int. 31:752-759.

3. Zatz, R., B. R. Dunn, T. W. Meyer, S. Anderson, H. G. Rennke, and B. M. Brenner. 1986. Prevention of diabetic glomerulopathy by pharmacologic amelioration of glomerular capillary hypertension. J. Clin. Invest. 77:1925-1930.

4. Hutchinson, F. N., M. Schambelan, and G. A. Kaysen. 1987. Modulation of albuminuria by dietary protein and converting enzyme inhibition. Am. J. Physiol. 253:F719-F725.

5. Scholey, J. W., P. L. Miller, H. G. Rennke, and T. W. Meyer. 1989. Effect of converting enzyme inhibition on the course of adriamycin-induced nephropathy. Kidney Int. 36:816-822. 
6. Keane, W. F., and B. E. Shapiro. 1990. Renal protective effects of angiotensin-converting enzyme inhibition. Am. J. Cardiol. 65:49I-53I.

7. Carretero, O. A., and A. G. Scicli. 1988. Kinins paracrine hormone. Kidney Int. 34:S52-S59.

8. Beierwaltes, W. H., and O. A. Carretero. 1989. Kinin antagonist reverses converting enzyme inhibitor-stimulated vascular prostaglandin $\mathrm{I}_{2}$ synthesis. $\mathrm{Hy}$ pertension (Dallas). 13:754-758.

9. Danckwardt, L., I. Shimuzu, G. Bonner, R. Rettig, and T. Unger. 1990. Converting enzyme inhibition in kinin-deficient brown Norway rats. Hypertension (Dallas). 16:429-435.

10. Hutchison, F. N., and V. I. Martin. 1990. Effects of modulation of renal kallikrein-kinin system in the nephrotic syndrome. Am. J. Physiol.258:F1237F1244.

11. Weibel, E. R. 1979. Stereological Methods: Practical Methods for Biological Morphometry. Vol. 1. Academic Press, Ltd., London. pp. 51-57.

12. Hirose, K., R. Osterby, M. Nozawa, and H. J. G. Gundersen. 1982. Development of glomerular lesions in experimental long-term diabetes in the rat. Kidney Int. 21:689-695.

13. Deen, W. M., J. L. Troy, R. Robertson, and B. M. Brenner. 1973. Dynamics of glomerular ultrafiltration in the rat. IV. Determination of the ultrafiltration coefficient. J. Clin. Invest. 52:1500-1508.

14. Meyer, T. W., and H. G. Rennke. 1988. Progressive glomerular injury after limited renal infarction in the rat. Am. J. Physiol. 254:F856-F862.

15. Miller, P. L., and T. W. Meyer. 1990. Effects of tissue preparation on glomerular volume and capillary structure in the rat. Lab Invest. 63:862-866.

16. Olson, J. L., and R. H. Heptinstall. 1988. Biology of disease. Nonimmunologic mechanisms of glomerular injury. Lab. Invest. 59:564-578.

17. Blantz, R. C., K. S. Konnen, and B. J. Tucker. 1976. Angiotensin II effects upon the glomerular microcirculation and ultrafiltration coefficient of the rat. $J$. Clin. Invest. 57:419-434.

18. Miller, P. L., H. G. Rennke, and T. W. Meyer. 1991. Glomerular hypertrophy accelerates hypertensive glomerular injury in rats. Am. J. Physiol. 261:F459-F465.

19. Wong, P. C., W. A. Price, A. T. Chiu, J. V. Duncia, D. J. Carini, R. R. Wexler, A. L. Johnson, and P. B. M. W. M. Timmermans. 1990. Nonpeptide angiotensin II receptor antagonists. VIII. Characterization of functional antagonism displayed by DuP 753, an orally active antihypertensive agent. J. Pharmacol. Exp. Ther. 252:719-725.

20. Timmermans, P. B. M. W. M., P. C. Wong, A. T. Chiu, and W. F. Herblin 1991. Nonpeptide angiotensin II receptor antagonists. TIPS (Trends Pharmacol. Sci.). 12:55-62.

21. Wong, P. C., W. A. Price, A. T. Chiu, J. V. Duncia, D. J. Carini, R. R. Wexler, A. L. Johnson, and P. B. M. W. M. Timmermans. 1990. Nonpeptide angiotensin II receptor antagonists. IX. Antihypertensive activity in rats of DuP 753, an orally active antihypertensive agent. J. Pharmacol. Exp. Ther. 252:726732.

22. Rhaleb, N.-E., N. Rouissi, F. Nantel, P. D’Orléans-Juste, and D. Regoli.
1991. DuP 753 is a specific antagonist for the angiotensin receptor. Hypertension (Dallas). 17:480-484.

23. Wong, P. C., W. A. Price, Jr., A. T. Chiu, J. V. Duncia, D. J. Carini, R. R. Wexler, A. L. Johnson, and P. B. M. W. M. Timmermans. 1990. Hypotensive action of DuP 753, an angiotensin II antagonist, in spontaneously hypertensive rats. Nonpeptide angiotensin II receptor antagonists: X. Hypertension (Dallas). 15:459-468.

24. Sokabe, H., and A. Grollman. 1967. A study of hypertension in the rat induced by infarction of the kidney. S. Texas Rep. Biol. Med. 25:257-264.

25. Warren, D. J., and T. F. Ferris. 1970. Renin secretion in renal hypertension. Lancet. i:159-162.

26. Chapman, A. B., A. Johnson, P. A. Gabow, and R. W. Schrier. 1990. The renin-angiotensin-aldosterone system and autosomal dominant polycystic kidney disease. N. Engl. J. Med. 323:1091-1095.

27. Anderson, S., H. G. Rennke, and B. M. Brenner. 1986. Therapeutic advantage of converting enzyme inhibitors in arresting progressive renal disease associated with systemic hypertension in the rat. J. Clin. Invest. 77:1993-2000.

28. Navar, G. N., and L. Rosivall. 1984. Contribution of the renin-angiotensin system to the control of intrarenal hemodynamics. Kidney Int. 25:857-868.

29. Ingelfinger, J. R., R. E. Pratt, K. Ellison, and V. J. Dzau. 1986. Sodium regulation of angiotensinogen mRNA expression in rat kidney cortex and medulla. J. Clin. Invest. 78:1311-1315.

30. Kriz, W. 1987. A periarterial pathway for intrarenal distribution of renin. Kidney Int. 31:S51-S56.

31. Sealey, J. E., J. D. Blumenfeld, G. M. Bell, M. S. Pecker, S. C. Sommers, and J. H. Laragh. 1988. On the renal basis for essential hypertension: nephron heterogeneity with discordant renin secretion and sodium excretion causing hypertensive vasoconstriction-volume relationship. J. Hypertens. 6:763-777.

32. Rosenberg, M. E., S. M. Kren, and T. H. Hostetter. 1990. Effect of dietary protein on the renin angiotensin system in subtotally nephrectomized rats. Kid ney Int. 38:240-248.

33. Pelayo, J. C., and J. Y. Westcott. 1991. Impaired autoregulation of glomerular capillary hydrostatic pressure in the rat remnant nephron. J. Clin. Invest. 88:101-105.

34. Naftilan, A. J., R. E. Pratt, and V. J. Dzau. 1989. Induction of platelet-derived growth factor A-chain and c-myc gene expressions by angiotensin II in cultured rat vascular smooth muscle cells. J. Clin. Invest. 83:1419-1424.

35. Fujiwara, Y., T. Takama, S. Shin, S. Ochi, M. Fukunaga, Y. Orita, and T. Kamada. 1989. Angiotensin II stimulates mesangial cell growth through phosphoinositide cascade. Kidney Int. 35:172.

36. Fuzibayashi, M., Y. Fujiwara, M. Fukunaga, K. Yokoyama, S. Ochi, S. Shin, Y. Orita, Y. Fukuhara, N. Ueda, T. Kamada, and A. Ando. 1990. Angiotensin II stimulates interleukin-6 release from cultured mouse mesangial cells. $J$. Am. Soc. Nephrol. 1:454.

37. Bianchi, C., J. Gutkowska, G. Thibault, R. Garcia, J. Genest, and M. Cantin. 1986. Distinct localization of atrial natriuretic factor and angiotensin II binding sites in the glomerulus. Am. J. Physiol. 251:F594-F602. 